\title{
Leaving Care: Unaccompanied Asylum- Seeking Young Afghans Facing Return
}

\author{
KIM ROBINSON AND LUCY WILLIAMS ${ }^{1}$
}

\section{Abstract}

Unaccompanied asylum-seeking children in the United Kingdom approach adulthood knowing that they will be encouraged or even forced to return to their countries of birth. Drawing on a project that promoted voluntary return to Afghanistan, we use interviews with twelve young people, professionals working in the Home Office and in education, local authorities, and voluntary-sector agencies to describe a complex area of immigration policy. We show how the state's obligations as "corporate parent" clash with increasingly punitive migration controls and with growing political scrutiny of public spending. We propose education as a way to prepare young people for futures as global citizens in either country of settlement or of origin.

\section{Résumé}

Les enfants non accompagnés demandeurs d'asile au Royaume-Uni évoluent vers l'âge adulte sachant qu'ils vont être incités ou même forcés à retourner à leurs pays d'origine. En nous basant sur un projet qui encourageait le retour volontairte à l'Afghanistan, et à l'aide d'entrevues avec douze jeunes personnes, ainsi que des professionnels du ministère de liIntérieur du Royaume-Uni (Home Office), des professionnels de l'éducation, des autorités locales, et des agences $d u$ secteur bénévole, nous dressons le portrait d'un domaine complexe de la politique en matière d'immigration. Nous montrons comment les devoirs de l'État dans son rôle de "parent institutionnel» se heurtent à des restrictions de plus en plus sévères sur la migration et à une attention politique intensifiée portée sur les dépenses publiques. Nous proposons l'éducation comme moyen de préparer les jeunes pour un avenir en tant que citoyens $d u$ monde, que ce soit dans les pays d'installation ou d'origine.

\section{Introduction and Context}

I $\mathrm{n}$ the United Kingdom, local authorities (LA), which include ports of arrival or asylum-screening centres, are responsible for the care of unaccompanied asylumseeking children (UASC) arriving in their area. Kent County Council (ксC), in the southeast corner of the United Kingdom, covers the Port of Dover, so is responsible for a relatively large percentage of the United Kingdom's asylumseeking children. The strategy document for Kent 2015-16 estimated that by March 2015, KCC would be caring for 365 UASC, representing 20 per cent of the overall care population. ${ }^{2}$ The increase in numbers of applications during the summer of 2015, however, has resulted in KCC now caring for over 720 unaccompanied children and having to open two new residential units to support new arrivals. ${ }^{3}$ State support for children in care in the United Kingdom can continue into adulthood, and the Children (Leaving Care) Act 2000 (CLCA) and the Children and Family Act (2014) protect careleavers. These young people can become classified as Appeal Rights Exhausted Care Leavers (ARECL) after reaching eighteen if their application to extend their temporary leave to remain in the United Kingdom (and subsequent appeals) fail. At this stage they risk detention and enforced return and, if a formal human rights assessment determines they have no further right to support in the United Kingdom, they can lose accommodation and support. For these young people, their status as adults refused protection trumps their claims as care-leavers and they face destitution, detention, and enforced return. Many are unwilling to return voluntarily and, even after their refugee cases have failed, actively 
seek fresh evidence and other means to prolong their stay in the United Kingdom. A significant proportion of UAsC supported by KCC are from Afghanistan, a dangerous country undergoing political, social, and economic transition but one the UK government considers safe enough for migrants whose refugee or humanitarian claims have failed. This is despite evidence from the International Organisation for Migration (IOM) and others 4 and the widely reported comments of the Afghan minister for refugees and repatriation, Hussain Alami Balkhi, who (cited by the Home Office themselves) ${ }^{5}$ stated a desire to renegotiate memorandums of understanding on returns with European countries to reflect the deterioration of security in Afghanistan.

The UASC population in Kent, as in the rest of the United Kingdom, includes girls and young women, but they are far fewer than boys and young men. Girls are almost always placed in foster care, unlike boys who are fostered only if found to be under sixteen. Girls are also less likely to be returned. For reasons of political and professional sensitivity, data on UASC are hard to access, and published data do not disaggregate ARECL numbers from the general data on people supported under adult support provisions or returned to Afghanistan. There is a sharp demarcation between the treatment of asylum-seekers determined as either over or under eighteen and they have access to very different services. ${ }^{6}$ The abrupt change in immigration category from child to adult also means that it is difficult if not impossible to follow the progress of care-leavers into the adult system.

The United Kingdom's emphasis on return as a durable solution for UASC reaching adulthood is in line with Europe-wide policy, but forced return of young people remains unpalatable to the public and thus problematic for policy-makers. Return, or repatriation, is one of the UNHCR "durable solutions" to refugee movements, emphasizing voluntary movement and a return "home."7 For many young people, however, return to countries of birth does not equate to return to a "home," as many feel that their home is now their country of asylum. ${ }^{8}$ Returnees may have retained few ties, and family members may have been lost or killed, and the empirical evidence noted by Lemberg-Pedersen highlights "that family tracing in Afghanistan is all but impossible."9 Other young people will have been born outside Afghanistan in refugee camps in Iran or Pakistan. In addition, returnees may be mistrusted and alienated, ${ }^{10}$ and this further prejudices the futures of young people lacking valuable local connections and skills. Nevertheless, EU governments including the United Kingdom insist that return is the best option for these young people as, being judged without grounds for protection, they have been found ineligible to remain in the countries where they have grown up.
Returning young Afghans to Afghanistan was also seen by some of our interviewees to have a symbolic significance for the United Kingdom, as it demonstrates the government's power to effect repatriation. In the context the United Kingdom's military involvement in Afghanistan this was seen as important by some.

This article draws on an evaluation of a return initiative carried out by the authors ${ }^{11}$ that targeted over 100 ARECL. The Positive Futures Project intended to encourage ARECL young Afghans to volunteer for AVR by giving them a return package enhanced with extra training and skills that would be useful once back in Afghanistan. The project was designed by a partnership that included representatives from the LA, the Home Office Assisted Voluntary Return team, the Immigration, Compliance and Enforcement (ICE) team, as well as voluntary sector agencies and a local Further Education college. Project funding was through the Return and Reintegration Fund (RRF). Ultimately it was unsuccessful, as none of the targeted young people agreed to return and take up the training offered, but the project raises fundamental issues for projects encouraging return as a "durable solution" for former UASC. It questions how UASC are educated and supported, how their connections to countries of origin are managed, how immigration cases should be handled, and most importantly how the needs of young people-for safety, belonging, and secure futurescan be assured. We argue that the marked unwillingness of this small group of young people to engage with efforts to encourage their return has important national and international implications. Service providers responsible for the care of UASC and policy-makers seeking durable solutions for young migrants without secure immigration status need to rethink their treatment of this vulnerable group.

\section{Legal Frameworks and Asylum Decision-making in the United Kingdom}

The processes by which young people are refused asylum and made ineligible for leaving care provisions have been well documented, ${ }^{12}$ and the Office of the Children's Commissioner's recent report explicitly examines two areas of problematic policy: the representation of UASC cases and their transition into adulthood. ${ }^{13}$ Warren and York reviewed the cases of twenty young people refused asylum and concluded that legal representation was often ineffective and inadequate. ${ }^{14}$ Gladwell and Elwyn summarize the issues facing unaccompanied asylum seeking Afghan children in the United Kingdom, ${ }^{15}$ and they identify the discretion in the system (to withdraw or continue support for example) and the specific issues affecting young people considered Appeal Rights Exhausted (ARE). These issues include their increasing vulnerability as support is cut, as 
well as problems with age determination. The age of a child as determined on arrival will determine the services to which he or she is entitled and, ultimately, the date when he or she will become subject to removal. ${ }^{16}$ Appeals against removal can be based on ongoing legal judgements, such as the KA ruling in July 2012, ${ }^{17}$ which found a systemic breach of the duty to endeavour to trace parents. Such legal challenges raise new grounds for appeal, and "fresh claims" can always be submitted if there is a material change in a person's case, such as evidence from country of origin or changes in personal circumstance. For example, the safety of chartered removal flights to Afghanistan is being currently challenged. ${ }^{18}$ Such disputes, shared and discussed among young people on social media, raise their hopes for the reassessment of cases. However, the increasing limitations on access to legal aid under the Legal Aid, Sentencing and Punishment of Offenders Act 2012 (LASPO), means that getting representation to restart cases and for judicial review has become increasingly difficult. In addition, changes to immigration rules in relation to article 8 of the ECHR-the Right of Private and Family Life-means that even starting a family in the United Kingdom may not be sufficient to prevent removal.

\section{Voluntary Return Schemes}

The uK government, in line with most receiving countries, emphasizes voluntary return schemes, and these, including AVR, which provides some material support for reintegration, are intended to allow migrants to return with some dignity. AVR schemes include an element of cash support as well as further support offered in-kind, in-country. This second element is intended to promote reintegration and a "sustainable return" that will discourage returnees from simply moving on to another country. "Pay-to-go" schemes such as AVR are run all over the world and are controversial to the extent that their "voluntary" nature can be disputed in cases in which migrants would prefer to stay but have little realistic alternative to return. ${ }^{19}$ The uk Home Office representatives we interviewed for the evaluation were categorical that the "voluntary" nature of its voluntary return programs is paramount, yet others of our informants saw voluntary return as a "least-worst" option for many migrants.

At the time of this project, AVR schemes in the United Kingdom were provided by Choices, a program run by the Refugee Action charity. Choices, whose services are closing on 31 December 2015, had a long record of providing impartial support for migrants considering return and had run services funded by the Home Office. Choices processed applications, provided pre-decision counselling and outreach schemes, and informed and assisted migrants considering return. They did not operate to targets, and their remit has always been to support decision-making rather to advocate any course of action. The successor to Choices as provider of voluntary return services has not yet been announced but is unlikely to be as independent or as supportive of its clients. AVR in the United Kingdom is no longer available to people in detention, and its absence again ratchets up the pressure on people facing detention, destitution, and deportation. The Home Office promotes voluntary departure schemes for migrants who may have overstayed and who wish to regularize their situation and potentially return to the United Kingdom later. Such schemes are clearly inappropriate for refugees who fear persecution in their countries of origin, and offering them to former asylum-seekers was construed by some informants as testament to the culture of disbelief that surrounds asylum claims and claimants.

\section{"Return" in an Afghan Context}

Gladwell and Elwyn consider the mechanisms involved in return and discuss why the young people in their study were so reluctant to take up offers of AVR. ${ }^{20}$ Their participants feared returning to a dangerous and unfamiliar environment where they felt they would have little chance of a future. Young people interviewed were not interested in the money or the support offered as part of AVR, and some saw absconding as an option, preferring to live below the state's radar without support to avoid enforced return. This desperate option was regarded as tenable by some, as they saw the United Kingdom as basically a safe country, even for people without rights to remain, unlike the alternative of Afghanistan.

Forced return is usually preceded by detention, and Gladwell and Elwyn describe how, when one young person was detained and/or returned, friends and acquaintances were more likely to drop out of the system. ${ }^{21}$ A clear picture emerges that young care-leavers do not want to return and will fight to stay in the United Kingdom. Many cannot imagine a future in Afghanistan, and the continuing state of unrest evidenced from multiple sources, including Facebook and social media, makes return a frightening prospect. Young people may have loose social networks that connect them back to countries of origin and to migrant communities, ${ }^{22}$ but they are still likely to be considered as outsiders in Afghanistan. Returning empty-handed is a further problem, especially for young men whose families may have invested heavily in getting them out of the country in the first place. Generalized insecurity and poverty in Afghanistan are also reported as problems for young people who have grown up in safety and relative affluence; their perceived Westernization may also cause them problems. Gladwell and Elwyn refer to assumptions that returnees 
are wealthy (and therefore worth kidnapping), involved with foreign agencies, and/or ideologically aligned with the West. ${ }^{23}$ Schuster and Majidi's research identifies three factors that inhibit sustainable return once removed to Afghanistan: ${ }^{24}$ deep economic loss, lack of transnational ties, and shame of failure, compounded by community suspicions of "contamination."

There are few educational opportunities open to returnees in Afghanistan, and finding employment in Kabul is difficult without family connections and/or advanced skills. Literacy in Dari and Pashtu was also important, and an informant in Kabul stated that "a returnee has to be above and beyond a young person who has been to high school and college here." 25 The long-term outcomes for returnees post-deportation are likely to include psychological damage, and it is clear that many returnees leave Afghanistan to seek safety elsewhere. ${ }^{26}$

Along with Morocco and Iraq, Afghanistan was identified in 2011 as the target of an EU-level drive to find durable solutions through the return of UASC. The European Return Platform for Unaccompanied Minors (ERPUM) aimed to develop reception centres in countries of origin and emphasized family reunification and tracing to reconnect children with their families and communities. It has been argued, however, that part of its failure "stems from normative questions concerning the illiberality of deportation powers as such" 27 and that the forced return of children remains a sensitive and controversial area of law. The ERPUM projects (I and II) were funded at the Eu level and aimed to "develop new methods for organizing family reunification and return for unaccompanied minors that need to return after receiving a final rejection of their asylum application." 28 Thus ERPUM and the Positive Futures project, while at very different scales, had similar goals-to repatriate young asylum-seekers whose claims for protection had been judged unfounded. ERPUM failed because of bureaucratic difficulties and because of the political sensitivities of EU governments returning children. The Afghan Ministry for Refugees and Repatriation was unwilling to offer much support for the project, partly as the result of limited funding for accepting children whose safety they could not guarantee. The Positive Futures project discussed here failed directly because the young people refused to engage with and could not trust AVR without assurances of security and without adequate family tracing. Two elements-legal and bureaucratic barriers in sending and receiving countries-combined with the active objection to return by asylum-seekers and their advocates are likely to affect all future projects.

\section{The Positive Futures Project}

Positive Futures was initiated because of the growing number of ARECL young people in Kent. The project recognized the group's need for pre-return skills and training, not least as some ARECL have had little education in the United Kingdom. It had two elements: preparation for training and the training itself. Crucially, the terms of project funding and the participation of the Home Office meant that potential trainees had to apply for AVR before becoming eligible for the training course. The original evaluation plan intended to involve the young people in ongoing discussions about the project-how they felt about it, their situation in the United Kingdom, and their proposed return to Afghanistan. As it turned out, the project was over almost before it began as, although great efforts were made to engage ARECL, through their case workers, open days, and a week of preproject study skills, none of the nine Afghan young men who attended these sessions agreed to sign up for AVR and join the Positive Futures project. During the whole evaluation (the pilot and the main project) we spoke to twelve ARECL young people, eight caseworkers working directly with the ARECL, and twelve members of the steering group, including representatives of the Home Office, Immigration Enforcement, project staff, and four experts with experience working with ARECL. The data collection design was approved by the University of Kent Ethics Committee, and the full evaluation has been published online. ${ }^{29}$

Throughout our interactions with these young unaccompanied refugees we struggled to avoid the traps created by the administrative categories devised by immigration status and tried to focus on the young people as individuals. Arriving as unaccompanied children, they lack a family to contextualize their experience. Focusing on their lives as UASC, or ARECL, therefore, risks essentializing them and underestimating their individuality and their local and international connections. This research sought to present the views of people whose voices are rarely heard and whose experience represents a reality that mainstream society does not want to acknowledge. We were able to engage in a reflexive process to develop an understanding of individual experiences that gave meaning to their social reality. Nevertheless, there are ongoing concerns about the role of researchers and humanitarian advocates working with asylum-seekers and refugees, which include the possibility of colluding with practices that work against the human rights of informants..$^{30}$ Research on deportation and removal could fall into this trap.

As stated above, this research is based on the experience of a small number of young people, as is common in projects seeking to engage potential returnees. We had no access to a larger data set, and young people without secure leave to remain are generally acknowledged to be hard to reach. ${ }^{31}$ We situate the experience of a small number of young people within a wider research field that has resonance 
for policy-makers internationally who struggle to support former UASC facing return to countries of origin. We aim to faithfully reflect the views of this small group of young people as expressed to us in a setting in which confidentiality was assured and where participants understood that we were impartial and unconnected to Social Services, the Home Office, or any other official agency.

\section{Lessons from the Project: A Lack of Educational Opportunities}

These UASC had had varied educational opportunities in the United Kingdom, as their routes into education were affected by many factors - not least their age assessment on arrival. Children placed in foster care are likely to receive more support and encouragement to study than those assessed as over sixteen and housed in semi-independent accommodation. These older children were, at the time, over the age for compulsory schooling so may not have been offered mainstream education. The local area is over 89 per cent white ${ }^{32}$ and schools are inexperienced at working with children with additional languages; they are reluctant to take on teenagers new to the UK school system. Many UASC in Kent have received education from a voluntary organisation funded by the LA that provides twenty hours of teaching per week in English, everyday maths, British culture, and some vocational skills. This is unlikely to meet the needs of the UASC, who arrive with little education and are unprepared to join mainstream schooling. Education provision is just one way that support for UASC differs across the United Kingdom, as in other British LAs, education post-sixteen has been more comprehensive. 33

Several of the young people interested in joining the project were functionally illiterate in their own language so were at a serious disadvantage when learning English or vocational skills. That said, they were enthusiastic about having a chance to study at a Further Education (FE) college. Our conversations and the reports written for the evaluation by the trainer and the keyworker show how the young people were very positive about participating and they were eager to learn. The poor mental health status of these young people, however, should not be overlooked. Worry and anxiety undermined their learning and shortened their attention span. One stated, "We are slowly going mad." They told us they could not sleep at night and were tired during class. Sleep disturbance was, in part, due to fear for the future and of night-time raids by the ICE teams but also may relate to pre-migration and flight experiences.

Education is valued highly in Afghanistan, and we heard that nothing short of a degree would allow a young person to return with dignity and a good chance of a livelihood. Indeed Schuster and Majidi state, "Where those deported are seen as shamed or contaminated, access to such networks may be withdrawn. Without networks to offer support and employment opportunities, integration into a community is almost impossible." 34

The young people we spoke to were motivated in part by the project's promise of some respite from reporting and from being detained and forcibly removed. One said, "The good thing that they say to us is that you don't need to go sign and that Immigration and the Police can't touch you because you are going to this course-that is exciting. We can walk free, we can go out free. We don't have to worry too much like we used to be. But we are still thinking-what's it going to be after three months? Same again—but at least we can breathe for three months."

\section{Lessons from the Project: AVR and Young Care- Leavers from Afghanistan}

The young people we spoke to were clear that return was not an option for them, and they stressed that the original reasons they left their homes still remain. They were also clear that they had often been told by their caseworkers about AVR and that they had discounted it. "We know about it! If you want to go back you can go but we don't want to-we come here from 2009 and we know about this stuff-we got a problem how can we go back?"

The Home Office's preferred option for ARECL remains, however, AVR. The alternatives-forced return or voluntary departure (by which migrants leave without support packages) - are both undesirable and in the case of forced return, expensive and traumatic for all involved. Our interviews with ICE made it clear that forced return is complex and involves locating and detaining young people. Enforcement raids are potentially public and traumatic events. The Home Office has a clear interest in keeping in touch with the young people so that they can note the progress of cases as well as keep their information systems up to date. A key indicator of the success of the Positive Futures project, from the Home Office's point of view, was that engagement encouraged young people who had not been reporting to re-present themselves and thus to place themselves back within the state's purview.

AVR is a contested subject, and we heard views from stakeholders ranging from those who saw it as a positive option to those who opposed it as a form of quasi non-voluntary removal. There was a majority view, however, that AVR is unlikely to be an attractive option for this group of young people because of their age and their sincere fear of return. This reluctance to volunteer to return was reinforced by their continuing hopefulness that they would be able to legitimize their stay in the United Kingdom. Some we spoke to felt that age and gender mattered and a masculine 
attitude to risk meant that, in their situation, "You'd take your chance" rather than accept voluntary return. Another informant considered that conditions in the United Kingdom, although not easy, were so much better than those in Afghanistan, that no amount of pressure or incentive would be enough.

\section{Lessons from the Project: AVR and Incentive to Return}

The project was not an incentive for any of the ARECL to apply for AVR. What was offered-training and the highest rate of financial reintegration support-did not outweigh their fears. When they met the Choices team at the end of the preliminary week, the young people, who had not fully understood that they must commit to return to receive the training, left the program, and those we were able to speak to were angry and very disappointed in how things had turned out. We were told,

We were thinking we can go to college, we can do anything, we can learn, but then they said we must sign and go back. I know that ... I've been in detention, I know that every single day about this thing, they can give some money and you can go back to Afghanistan to live there-what am I going to do with that money if I haven't got family? If I go somewhere and they see me I've got money, they lift from me, and get money from me, they might kill me as well. I've got problems as well, I've got problem with that people as well-if they find me out, they are not give me a chance. It's not right.

His friend continued, "Those people, they are not going to listen to you, they are going to shoot you. It's not like England!”

This and other data collection exercises ${ }^{35}$ has shown that while their lives are very hard in the United Kingdom-being disqualified from education and employment and threatened with detention, homelessness, and destitution $^{36}$-it is still a great deal better than what they expect to find in Afghanistan. As the report on a UK Border Agency and Foreign and Commonwealth Office workshop acknowledges, the "push factors" at the disposal of the Home Office are rarely enough to change a young person's mind:

Push factors include: the prospect of detention and enforced removal (although there are differing views as to how much this prospect influences decisions); the lack of options or opportunities in the UK; the tightening of immigration laws (including moves to further limit legitimate migration); destitution-sometimes triggering the need to resort to unlawful activity in order to survive; and a mismatch of reality with optimistic, or even misguided, expectations of life in the uk prior to arrival ... However, compelling factors such as destitution can limit the individual's ability to engage with long-term considerations and planning for return. 37

Our discussions with experts within and outside the steering group indicates skepticism about the appropriateness of AVR for ARECLS. Some service providers involved in this project felt that AVR should be presented to young asylumseekers as soon as they arrived in the United Kingdom, while others were reluctant to bring up the subject for fear of implying a lack of confidence in the young person's asylum claim and their right to be in the United Kingdom. Finding the right time to raise the delicate issue of returning "home" is difficult. Our conversations with young people illustrated that while they were clear about AVR as an option, they had not realized how tightly enmeshed it was within the project. This failure of communication led directly to the collapse of the project, as while members of the steering group were clear that openness and honesty with the young people was paramount, the centrality of AVR had been downplayed. Within the general skepticism about the appropriateness of voluntary return for this group, we heard the view that former asylum-seekers will take up AVR only once they had reached a point when return feels desirable or inevitable. These young people have not reached this point and are genuinely afraid of what is waiting for them in Afghanistan and still hoping for leave to remain at "home" in the United Kingdom.

There were discussions about the levels of support offered to returning migrants and of the ratio of cash to paymentin-kind. We heard that few migrants return because of the financial incentive and that Afghanistan is not short of tradespeople or training programs. We were told by an expert, "Vocational training is not enough, there are loads of training-providers in Afghanistan. Lots of people know how to do these things who have networks and contacts and don't have the disadvantages that returnees have-it's helpful to the extent that any training is helpful but not the critical factor that will change things unless it was linked to completely reliable and verified job-creation servicesthat's the only way it would have made a difference."

\section{Conclusions: Returning Young Unaccompanied Asylum-Seekers}

We have described some of the reasons, common to many receiving countries, why projects seeking to return young unaccompanied people to countries of origin voluntarily, fail. Without wishing to promote the option of return, we recognize that some young people's best interests would be served by a genuinely informed and sensitively arranged return, to at least "test the water" in their countries of origin. 
The final section of this paper thus considers what the Positive Futures project taught us about how such an option could be designed.

\section{Comprehensive Training and a Bigger Project}

The young people involved in this project made it clear that return was not an option for them. The majority of the steering group, however, felt that return was in the best interest of the child and that developing pre-return packages had some value. While it was inappropriate for this group of young people, we feel that some young people, from countries that are safe and developing, could benefit from prereturn training packages. There are therefore some general lessons to draw from this project.

Several steering group members felt that the length of time allotted to the project was too short. Insufficient time was allotted to gain the trust of the young people, to find out about their needs, to build links in countries of origin, and to accustom them to the situation that they would face there. The terms of the funding and Home Office's concerns that a longer course might act as a pull factor for more asylum claimants limited the project, but there was a common feeling that the lead-in time was too short and the training too superficial to be valued by the young people. In the case of the Afghan young people, however, they challenged the idea that any kind of training could be sufficient to persuade them to return.

During the evolution of the project, from an idea before 2012 to a funding application in 2013, the project became less ambitious. The originators of the project attempted to engage agencies working in Afghanistan to explore what the options for returnees might be. They consulted the IOM, who have significant links in Afghanistan and who provide support for returning migrants, on the sorts of skills that were likely to be useful on return. They built links with organizations such as Afghan Action and the Afghan Professionals' Network. A more extended program could have allowed the young people to think, talk over their options, and settle into preparatory study without having to commit to return. After this introduction, they could choose a course of study that would suit them and give them a realistic chance of work on return. Staff at the FE college spoke of how the young people were uncomfortable in the classroom; they arrived late, found it hard to concentrate, and were excited but suspicious of their unfamiliar surroundings. Staff felt that e-learning techniques, including Skype, could have allowed them to access learning in an environment where they felt comfortable. They could have overcome their nervousness and fear of being "trapped" at the course while building skills and familiarity with the college. This approach would also have been more cost effective and a "softer introduction" to learning for young people living chaotic lives.

In the current political climate, a comprehensive course of study is unlikely to be politically acceptable, but we argue that the fears that prevent funding - that such a course is a "pull factor" and that investment should not be made in people ineligible for support in the country-are not insurmountable. We find no evidence to support the belief that a course would act as a pull factor, and, given the cost and political sensitivity of detention, forced removal, and destitution, interventions supporting return could be justified on financial grounds and certainly on ethical grounds.

\section{A "Cultural" Approach to Supporting UASC and Young People}

Introducing voluntary return to young people when they are facing the loss of their support from social services is too late. We heard from the young people themselves and many other parties that they were too scared and too angry to accept return and AVR at this late stage.

An alternative approach could be to introduce the option of return much earlier in care planning. Training and support for social workers who have to balance the tension between care and immigration matters is critical here. $3^{8}$ Careful and sensitive handling is needed to ensure that AVR is presented as genuinely voluntary and a positive choice. Such an approach could run alongside the provision of good and equitable educational opportunities in mainstream UK schools leading to British qualifications. Education could include mother-tongue classes, which would support learning generally and help young people develop a sense of pride in their own heritage. It could encourage a sense of belonging and biculturalism that would allow them space to think positively about returning to Afghanistan.

For the young people we spoke to, Afghanistan is not "home"; home is where they have grown up, and they know nothing about their country of birth. Most of them have few if any connections to draw on, and those who do are unlikely to admit to them for fear they will be used to force them back. Connections and social networks in Afghanistan could be promoted from the United Kingdom, and family-tracing services could be used proactively and independently of immigration processes to develop the few links these young people have. Such a cultural approach is in line with Elaine Chase's findings ${ }^{39}$ and the "Life projects" approach discussed by Matthews. ${ }^{40}$ This approach, connected to Article 3 of the UNCRC and developed by the Council of Europe ${ }^{41}$ aims to promote the best interest of the child and the future prospects of all concerned with their welfare and protection. Matthews writes, "The Committee of Ministers envisages life projects ... as being implemented 
either in the host country or in the host country and in the country of origin or in the country of origin or, in the specific case of family reunion, in a third country in which the parents are lawfully settled." 42

Equipping young persons with cultural skills appropriate to a future in the United Kingdom as well as in their country of origin surely has great potential for supporting them to be truly contributing citizens wherever their lives take them.

\section{Changing the Political Climate}

Funding for ARECL remains contentious. Local authorities are financially responsible for providing care (subject to a human rights assessment), while the Home Office's role is as an enforcement agent. The resulting tension over financial liability needs to be resolved if more holistic approaches to the care and support of ARECL are to be achieved. We find it disturbing that a group of young people who have already experienced disruption, loss, and disadvantage in their short lives should be treated as a burden rather than as potential contributing members of society, whether in the United Kingdom or in Afghanistan. Writing ten years ago, Blitz, Sales, and Marzano argued, "Domestic interest based arguments, rather than those founded on the protection of human rights, appear to be driving the policy-making agenda. Thus returns are portrayed as a means of relieving the burden on Britain's social services, and as a means of placating a public opinion and media that has become increasingly hostile to immigrants and asylum seekers."43

This observation has become only more striking in the intervening years. While we argue that not enough has been invested in the care and education of UAsc before they reach eighteen, we find it unethical and counterintuitive not to support their transition into adulthood, either through allowing them to work or through meaningful education or training programs. Our reflections on the Positive Futures project highlight some of the complexities experienced by Afghan ARECL. The project attempted to tackle one area of this complexity through an innovative approach, but the project failed, we would argue, because of the political climate in the United Kingdom and beyond. Afghan careleavers are well aware that asylum decision-making is not equivalent across Europe, and we heard examples of young people leaving the United Kingdom clandestinely and gaining refugee status elsewhere. Even in this small sample within one local authority, these young people have had an inconsistent experience, with fostered children better able to access mainstream education than those supported in independent housing.

Government policy on migration controls still privileges neo-classical models of "push and pull" to explain and understand the motivations of migrants and refugees, despite academic research that now generally accepts pushpull theories as outdated and unhelpful in predicting migration decision-making. ${ }^{44}$ Conversations with steering group members made it clear that the project design was driven largely by funding streams that insisted on a strong "push"obligatory application for AVR before Phase Two, combined with a weak "pull"- enough to get the ARECL into the classroom but not enough to encourage new asylum-seekers into the country. This project failed, as have other projects, because it did not recognize that young people seeking safety in the United Kingdom are active agents who will strive for their own best interests, which they perceived to be served by remaining in their UK home, not in countries of origin. 45

Kim Robinson is a lecturer in social work. She has been a social work practitioner and manager in community health and refugee services for over twenty-five years in Australia and in the United Kingdom. Her research interests include the application of critical theory perspectives, particularly post-structuralism and feminism, to inform social work practice and education. She is also writing on domestic violence and refugees, and unaccompanied asylum-seekers leaving care. After working in the United Kingdom for the past thirteen years she has returned to Australia as lecturer in social work at Deakin University. The author may be contacted at kim.robinson@deakin.edu.au.

Lucy Williams is a visiting senior research fellow, University of Kent, and independent researcher. She has a longterm research interest in the health and social well-being of migrants, particularly those who are facing destitution, detention, and deportation. The author may be contacted at l.a.williams@kent.ac.uk.

\section{Notes}

1 Equal authorship.

2 Jill De Paolis, "Kent's Looked-After Children and Care Leavers Strategy," draft March 2015, http://www.kent.gov. uk/_data/assets/pdf_file/oo13/32251/Looked-after-Children-and-Care-Leavers-Strategy.pdf.

3 "Kent Sees 'Unprecedented' Increase in Lone AsylumSeeker Children," вBC, 3 September 2015, http://www.bbc. co.uk/news/uk-england-kent-34139364.

4 Liza Schuster, "Afghan Perspectives on ERPUM," in The Deportation of Unaccompanied Minors from the EU: Family Tracing and Government Accountability in the European Return Platform for Unaccompanied Minors (ERPUM) Project, workshop report 3 May, ed. Martin Lember-Pedersen, 
Liza Schuster, Rebecca Stern, Matthew J. Gibney, and Jennifer Allsopp, 13-15 (Oxford: Refugee Studies Centre, Oxford Department of International Development, University of Oxford, 2013).

5 Home Office, Country Information and GuidanceAfghanistan: Security and Humanitarian Situation, version 2 (London: Home Office, 2015), https://www.gov.uk/ government/uploads/system/uploads/attachment_data/ file/455129/CIG_AFG_security_situation_August_2015.pdf.

6 Heaven Crawley, Child First, Migrant Second: Ensuring That Every Child Matters (London: Immigration Law Practitioners Association, 2006).

7 UNHCR, "Durable Solutions," http://www.unhcr.org/ pages/49c3646cf8.html.

8 Matthew J. Gibney, "Ethical Reflections on ERPUM," in Lember-Pedersen et al., Deportation of Unaccompanied Minors from the $\mathrm{EU}, 23-8$.

9 Martin Leberg-Pedersen, "The Evolution of the ERPUM Project," in Lember-Pedersen et al., Deportation of Unaccompanied Minors from the $\mathrm{EU}, 4$

10 Elaine Chase, Future Citizens of the World? The Contested Futures of Independent Young Migrants in Europe (Oxford: Refugee Studies Centre, Oxford Department of International Development, 2013); Nathalie Peutz, "Embarking on an Anthropology of Removal," Current Anthropology 47, no. 2 (April 2006): 217-41; Liza Schuster and Nassim Majidi, "Deportation Stigma and Re-migration," Journal of Ethnic and Migration Studies 41, no. 4 (2015): 635-52.

11 Kim Robinson and Lucy Williams, Positive Futures: A Pilot Project to Develop and Test a Model to Assist Appeal Rights Exhausted Care Leavers to Consider Assisted Voluntary Return, 2014, South East England Councils, http:// www.secouncils.gov.uk/wp-content/uploads/2012/o4/ Positive-Futures-Evaluation-Report-Final-18-Aug.pdf.

12 Jim Wade, "Preparation and Transition Planning for Unaccompanied Asylum-Seeking Young People: A Review of Evidence in England," Children and Youth Services Review 33 (2011): 2424-30; Francis Wright, "Social Work Practice with Unaccompanied Asylum-Seeking Young People Facing Removal," British Journal of Social Work 44, no. 4 (2014): 1027-44.

13 Adrian Matthews, "What's Going to Happen Tomorrow?" Unaccompanied Children Refused Asylum (London: Office of the Children's Commissioner, 2014).

14 Richard Warren and Sheona York, How Children Become "Failed Asylum Seekers": Research Report on the Experiences of Young Unaccompanied Asylum-Seekers in Kent from 2006 to 2013, and How "Corrective Remedies" Have Failed Them (Canterbury: Kent Law Clinic, University of Kent, 2014).

15 Catherine Gladwell and Hannah Elwyn, Broken Futures: Young Afghan Asylum Seekers in the UK and in Their Country of Origin, Research Paper No. 246 (Geneva: UNHCR Policy Development and Evaluation Service, 2012), http:// www.unhcr.org/5098d2679.html.
16 Katia Bianchini, "Unaccompanied Asylum-Seeker Children: Flawed Processes and Protection Gaps in the UK," Forced Migration Review 37 (2011): 52-3.

17 KA (Afghanistan) \& Ors v Secretary of State for the Home Department [2012] EWCA Civ 1014 (25 July 2012), http:// www.bailii.org/ew/cases/EwCA/Civ/2012/1014.html.

18 http://www.politics.co.uk/blogs/2015/o4/22/afghandeportations-cancelled-at-last-minute-ahead-of-possib. "Duncan Lewis Solicitors Obtain Unprecedented Generic Injunction from the Court of Appeal in Relation to Removals to Afghanistan," 24 August 2015, http://www. duncanlewis.co.uk/news/Duncan_Lewis_Solicitors_ obtain_unprecedented_generic_injunction_from_the_ Court_of_Appeal_in_relation_to_removals_to_Afghanistan._\%2824_August_2015\%29.html.

19 David Turton and Peter Marsden, "Taking Refugees for a Ride? The Politics of Refugee Return to Afghanistan," Afghanistan Research and Evaluation Unit, Issues Paper Series European Commission Humanitarian Aid Office, 2002; Richard Black, Michael Collyer, and Will Somerville, Pay-to-Go Schemes and Other Noncoercive Return Programs: Is Scale Possible? (Washington DC: Migration Policy Institute, 2011).

20 Gladwell and Elwyn, Broken Futures.

21 Ibid.

22 Karen Wells, "The Strength of Weak Ties: The Social Networks of Young Separated Asylum Seekers and Refugees in London," Children's Geographies 9, nos. 3-4 (2011): 319-29.

23 Gladwell and Elwyn, Broken Futures.

24 Liza Schuster and Nassim Majidi, "What Happens PostDeportation? The Experience of Deported Afghans," Migration Studies 1, no. 2 (2013): 221-40; Schuster and Majidi, "Deportation Stigma and Re-migration," Journal of Ethnic and Migration Studies 41, no. 4 (2015): 635-52.

25 Gladwell and Elwyn, Broken Futures, s. 6.7.

26 Schuster and Majidi, "Deportation Stigma and Re-migration"; Schuster, "Afghan Perspectives on ERPUM."

27 Martin Lemberg-Pedersen, "The Rise and Fall of the ERPUM Pilot: Tracing the European Policy Drive to Deport Unaccompanied Minors," Refugee Studies Centre Working Paper Series No. 108, April 2015.

28 ERPUM (2014): 6, cited in ibid., 7.

29 Robinson and Williams, Positive Futures.

30 Heike Drotbohm and Ines Hasselberg "Deportation, Anxiety, Justice: New Ethnographic Perspectives," Journal of Ethnic and Migration Studies 41, no. 4 (2015): 551-62; Susann Huschke, "Giving Back: Activist Research with Undocumented Migrants in Berlin," Medical Anthropology 34, no. 1 (2015): 54-69.

31 Alice Bloch, Nando Sigona, and Roger Zetter, Sans Papiers: The Social and Economic Lives of Young Undocumented Migrants (London: Pluto, 2014).

32 "Equality and Diversity," Kent County Council, http:// www.kent.gov.uk/about-the-council/information- 
and-data/Facts-and-figures-about-Kent/equalityand-diversity-data.

33 Matthews, "What's Going to Happen Tomorrow?"

34 Schuster and Majidi, "What Happens Post-Deportation?," 231.

35 Ibid.; Gladwell and Elwyn, Broken Futures; Matthews, "What's Going to Happen Tomorrow?"

36 Lucy Williams, "From Immigration Detention to Destitution," Criminal Justice Matters 99, no. 1 (2015): 12-13.

37 Steven Hall, Assisted Voluntary Returns: Working Together for Greater Effectiveness (WP1193), conference report 4-6 July 2012, https://www.wiltonpark.org.uk/conference/ wp1193/.

38 Kim Robinson, "Voices from the Front Line: Social Work with Refugees and Asylum Seekers in Australia and the UK," British Journal of Social Work 44, no. 6 (2013): 1602-20.

39 Elaine Chase, "Security and Subjective Wellbeing: The Experiences of Unaccompanied Young People Seeking Asylum in the UK," Sociology of Health \& Illness 35, no. 6 (2013): 858-72.
40 Matthews, "What's Going to Happen Tomorrow?" 82-8.

41 Council of Europe, "Recommendation CM/Rec (2007)9 of the Committee of Ministers to Member States on Life Projects for Unaccompanied Migrant Minors," https:// wcd.coe.int/ViewDoc.jsp?id=1164769.

42 Ibid., 83, emphasis in the original.

43 Brad Blitz, Rosemary Sales, and Lisa Marzano, "NonVoluntary Return? The Politics of Return to Afghanistan," Political Studies 53, no. 1 (2005): 196.

44 Stephen Castles, "Twenty-First-Century Migration as a Challenge to Sociology," Journal of Ethnic and Migration Studies 33, no. 3 (2007): 351-71; Stephen Castles and Mark J. Miller, The Age of Migration: International Population Movements in the Modern World, 4th ed. (London: Macmillan, 2009).

45 We acknowledge the valuable comments of the three anonymous reviewers of this text.

(C) Kim Robinson and Lucy Williams, 2015. This open-access work is licensed under a Creative Commons Attribution-NonCommercial 4.0 International License, which permits use, reproduction and distribution in any medium for non-commercial purposes, provided the original author(s) are credited and the original publication in Refuge: Canada's Journal on Refugees is cited. 